\title{
Adjudicating pathological criminal incapacity within a climate of ultimate issue barriers: A comparative perspective
}

\author{
Geert Philip Stevens \\ Department of Public Law, University of Pretoria, South Africa
}

\begin{abstract}
A B S T R A C T
Mental health experts are increasingly being utilised by the criminal justice system to provide assistance to courts during the assessment of issues falling beyond the knowledge and/or experience of the courts. A particular domain where the assistance of qualified psychiatrists and psychologists is becoming essential is where the defence of pathological criminal incapacity falls to be assessed. Mental health professionals testifying during trials where the defence of pathological criminal incapacity is raised will present opinion evidence which is one of the exceptions to the rule of inadmissibility of opinion evidence. Mental health professionals providing their opinion evidence are, however, prohibited from expressing opinions on so-called "ultimate issues" upon which only the court may ultimately rule upon. The latter rule is also commonly known in practice as the "ultimate issue" rule which presents multifaceted challenges in respect of the application of the defence of pathological criminal incapacity. In this article, the author assesses the application of the ultimate issue rule with reference to the defence of pathological criminal incapacity as it operates within the South African criminal law context. A comparative analysis is also provided with reference to the rule as it operates in the United States of America and more specifically Federal Rule 704. It is concluded that the ultimate issue rule unnecessarily restricts testimony provided by mental health professionals as such placing a barrier on such evidence. As such, it is argued that the rule is superfluous as it remains within the discretion of the trier of fact to decide as to what weight to attach to such evidence.
\end{abstract}

Melrose said: "But of course, perjury seldom plays a role in the testimony of so-called expert witnesses. It is only too easy for both defense and prosecution to find honest authorities who oppose each other diametrically in regard to the same phenomenon, even in such a supposedly exact science as ballistics, and when the human element enters, consistency goes right out the window. Dr Brixton, for example, believes that a man who has tried to get himself mutilated can be held responsible for no subsequent act however criminal. I wager that the prosecution psychiatrist will find the same fact utterly negligible." (Thomas Berger) ${ }^{1}$

\section{Introduction}

Mental health professions are increasingly being utilised by the criminal justice system to provide assistance in the assessment of issues beyond the knowledge or experience of the courts. One of the most important domains where the expertise of qualified psychiatrists and psychologists is becoming essential denotes the assessment and application of the defence of criminal incapacity. These mental health professionals will accordingly be requested by courts to assess individuals allegedly having lacked criminal capacity at the time of the commission of the offence and to consequently provide an opinion as to the mental

E-mail address: philip.stevens@up.ac.za.

${ }^{1}$ Meyer, R.G., Landis, E.R. and Hays, J.R., Law for the psychotherapist, Norton (1988) 220. state of the individual at the time of the offence. It is trite that the evidence presented by psychiatrists and psychologists within the paradigm of criminal capacity takes the form of expert opinion evidence. ${ }^{2}$

2 Zeffert, D.T. and Paizes, A.P. The South African law of evidence, 2 ed. LexisNexis (2009) 309-329; Schwikkard, P.J. and Van der Merwe, S.E. Principles of evidence, 3 ed. Juta (2009) 83-103; Meintjes-Van der Walt, L. Expert evidence in the criminal justice process, Rozenberg (2001) 63-84; Alan, A. The psychologist as expert witness in C. Tredoux, D. Foster, A. Alan, A. Cohen and D Wassenaar, (eds) Psychology and law, Juta (2005) 287-314 (hereinafter Tredoux et al.); Alan, A. and Meintjes-Van der Walt, L. Expert evidence in S. Kaliski (ed) Psycholegal assessment in South Africa, Oxford (2006) 342-355; Freckleton, I. and Selby, H. Expert evidence - Law, practice, procedure and advocacy, Lawbook Co. (2005) 11-20; Halleck, S.L. Law in the practice of psychiatry - A handbook for clinicians, Plenum Medical Book Co. (1980) 195-206 and 207-224; Shapiro, D.L. Forensic psychological assessment - An integrative approach, Allan and Baron (1991) 162-183 and 199-204; Guttmacher, M.S. The role of psychiatry in law, Thomas, Springfield (1968) 74-92; Hess, A.K. Serving as an expert witness in A.K. Hess and I.B. Weiner (eds) The handbook of forensic psychology, Wiley (1999) 501-520; Sales, B.D. and Shuman, D.W. Experts in court - Reconciling law, science and professional knowledge, American Psychological Association (2005) 3-12; Meintjes-Van der Walt, L. Thoughts on the presentation and evaluation of scientific evidence, South African law journal (2003) 352-372; Gilmer, B.T., Louw, D.A. and Verschoor, T. Forensic expertise: the psychological perspective, South African journal of criminal justice (1995) 259-270; Carstens, P.A. Setting the boundaries for expert evidence in support of the defence of medical negligence - Michael $v$ Linksfield Park Clinic (Pty) Ltd 2001 (3) SA 1188 (SCA), Journal of contemporary Roman-Dutch law (2002) 420-436; Slovenko, R. Expert testimony: use and abuse, Medicine and law (1993) 627-641. See also Du Toit, E., De Jager, F.J., Paizes, A., Skeen, A. and Van der Merwe, S. Commentary on the Criminal Procedure Act, Juta (2012) 24-12-24-17 (hereinafter Du Toit et al.); Melton, G.B., Petrilla, J., Poythress, N.G. and Slobogin, C. Psychological evaluations for the courts, Guilford Press (2007) 577-605; Carstens, P.A. and Pearmain, D. Foundational principles of South African medical law LexisNexis (2007) 860-862. 
Expert evidence is one of the exceptions to the general rule that evidence of opinion is inadmissible. ${ }^{3}$ The general rule is that opinion evidence is inadmissible due to the irrelevance thereof. The exception to the latter rule is when the issue is of such a nature that the opinion of the expert, in this case that of the psychiatrist or psychologist, can provide assistance to the court to adjudicate the matter. ${ }^{4}$ The opinion of an expert will accordingly be admissible to provide the court with scientific information which is likely to fall outside the experience and knowledge of the court. ${ }^{5}$ The converse is, however, also true. If the particular opinion evidence deals with a matter that the court can decide upon in the absence of such evidence, the opinion evidence will be deemed irrelevant and inadmissible. The main criterion for assessing the admissibility of such evidence can be traced to the relevance thereof. ${ }^{6}$ According to Zeffert and Paizes an opinion will be relevant if it can assist the court and if the witness is better qualified to form such an opinion. ${ }^{7}$ There are generally two exceptions to the general "ban" against opinion evidence. The first exception entails the opinion of a lay person as to facts observed by such a person and where it is reasonably inevitable for the witness to separate observed facts from the inferences drawn from the observed facts. ${ }^{8}$ It is consequently often difficult to distinguish between facts and opinion of such witness. The second exception relates to the opinion evidence presented by a witness who by way of skill, experience and competence is in a better position to draw inferences from the facts than the court due to the fact that the subject-matter requires skill, knowledge or expertise beyond the normal experience of the court. ${ }^{9}$ For purposes of this contribution, emphasis will fall on the second exception relating to expert evidence. One of the principle motivations for the exclusion of opinion evidence is predicated upon the premise of protecting the function of the trier of fact or judicial authority and entails that a witness should refrain from expressing opinion evidence on issues that the court itself has to decide upon and accordingly the witness should not "usurp" the function of the court. The latter principle is more commonly referred to within the law of evidence as the socalled "ultimate issue" principle. ${ }^{10}$ In $S$ v Harris, ${ }^{11}$ Ogilvie Thomson JA indirectly encroached the ultimate issue rule by stating ${ }^{12}$ :

“... in the ultimate analysis, the crucial issue of appellant's criminal responsibility for his actions at the relevant time is a matter to be determined, not by the psychiatrists, but by the Court itself. In determining that issue the Court - initially, the trial Court; and, on appeal, this Court - must of necessity have regard not only to

\footnotetext{
3 Zeffert, D.T. and Paizes, A.P. supra note 2 at 309; Schwikkard, P.J. and Van der Merwe, S.E. supra note 2 at 83-84; See also Dennis, I. The law of evidence, Sweet and Maxwell (2007) 847 where it is noted that the general rule according to the common law entails that a witness may only present evidence of facts to which they have personal knowledge of and may not express their opinions of what happened or may have happened. See also Du Toit et al. supra note 2 at 24-12-24-17.

${ }^{4}$ Ibid.

5 Alan, A. and Meintjes-Van der Walt, L. in Kaliski, S. supra note 2 at 342-343; Schwikkard, P.J. and Van der Merwe, S.E. supra note 2 at 87.

6 Schwikkard, P.J. and Van der Merwe, S.E. supra note 2 at 87; Zeffert, D.T. and Paizes, A.P. supra note 2 at 309-310.

7 Zeffert, D.T. and Paizes, A.P. supra note 2 at 311; Schwikkard, P.J. and Van der Merwe, S.E. supra note 2 at $87-88$.

8 Ibid. See also Wigmore, J.H. Evidence in trials at common law, Little, Brown (1978) par 1918 where he states that the true essence of the opinion rule simply relates to the exclusion of supererogatory evidence. He notes: "It is not that there is any fault to find with the witness himself or the sufficiency of his sources of knowledge or the positiveness of his impression; but simply that his testimony otherwise unobjectionable, is not needed, is superfluous."

9 Ibid. See also S v Nangatuuala and another 1997 (4) SA 766 (SWA); Gentiruco AG v Firestone SA (Pty) Ltd 1972 (1) SA 589 (A) at 616 G-H.

${ }^{10}$ Paizes, D.T. and Zeffert, A.P. supra note 2 at 310-314; Schwikkard, P.J. and Van der Merwe, S.E. supra note 2 at 88.

11 S v Harris 1965 (2) SA 340 (A).

12 At 365 B-C.
}

the expert medical evidence but also to all the other facts of the case, including the reliability of appellant as a witness and the nature of his proved actions throughout the relevant period."

The question which falls to be assessed is whether the ultimate issue rule should still be retained in our current rules of evidence. Within a climate of rapid developments in science and technology also with reference to the sciences of psychiatry and psychology, the "gap" between a layman's knowledge and expert knowledge is increasingly expanding. In the ultimate pursuit for truth and justice, various questions arise as to the admissibility, scientific reliability and validity of psychiatric and psychological evidence. Van Kampen illustrates the anomaly as follows ${ }^{13}$ :

"Over many centuries, science has become pivotal to our understanding of (human) nature and its contribution to legal decision making processes has increased dramatically. But as the involvement of science itself, and various techniques based upon its insights grew, so did a number of problems related to the use of such knowledge by legal institutions."

\section{And further:}

"The vast range of problems related to the use of (applied) scientific or otherwise specialised knowledge by legal institutions that have been identified over the years - and the manifest presence of some of these problems in more well-known miscarriages of justice has made expert evidence one of the most hotly debated topics in legal literature."

Within the ambit of the defence of pathological criminal incapacity as it operates within the context of South African criminal law, expert evidence is statutorily provided for. Proper statutory recognition of expert evidence is, however, only one step towards the proper application of expert evidence in cases where the defence of criminal incapacity and more specifically, pathological criminal incapacity, is raised. Obstacles such as the ultimate issue rule, reliability and validity further place a barrier on the acceptance of expert evidence which will have to be addressed. The latter is further exacerbated by the divergent views of the behavioural sciences as opposed to the legal profession. Despite the necessity and pivotal role of expert evidence in cases where criminal capacity is in issue, courts frequently approach such evidence with great caution, scrutiny and scepticism. Melton et al. encapsulate this dilemma by stating ${ }^{14}$ :

"To some extent, this antipathy stems from the belief that mental health professionals too often try to answer legal questions for which there are no good behavioural science answers - or, worse, are merely selling their testimony to the highest bidder. But it also flows from the fact that even when clinicians have something useful to say and are eager to maintain their integrity, their message is often obscured or confused. Their reports are perceived as conclusory and filled with jargon; their testimony is viewed as hard to follow (on direct examination) and befuddled (on cross-examination)."

\footnotetext{
${ }^{13}$ Van Kampen, P.J.C. Expert evidence compared - Rules and practices in the Dutch and American Criminal justice system, Intersentia (1998) at 4-5. See also Redmayne, M. Expert evidence and criminal justice, Oxford University Press (2001) at 36 where it is noted: "Fact finders need to analyse expert evidence and combine it with the other evidence that is presented to them; for their part, experts need to present their evidence in a manner that facilitates this task. These points are obvious, even banal. What is interesting is that their implementation is challenging, and even controversial."

14 Melton et al. supra note 2 at 577.
} 
Dahl similarly refers to the ultimate issue problem and its impact on expert psychiatric evidence by stating ${ }^{15}$ :

"One reason for resistance to the use of psychiatric knowledge by the law is lingering doubt about the scientific validity of psychiatry. However, legal decision-makers are also concerned that incorporation of psychiatric concepts into the criminal law will impair the ability of the law to achieve its policy objectives. They fear two developments: one, that psychiatrists will have increasing influence on ultimate legal determinations; and two, that the law will become dependent on concepts that belong to an outside discipline."

In this contribution the author will assess the practical implications of the ultimate issue rule on the application and assessment of the defence of pathological criminal incapacity within the South African criminal law. A comparative perspective will be provided in respect of the application of the ultimate issue rule within the context of Federal Rule 704 of the United States of America.

The practicality of the ultimate issue rule during the application of the defence of pathological criminal incapacity will be addressed and it will be indicated that the ultimate issue rule unnecessarily restricts the presentation of expert evidence in support of the defence of pathological criminal incapacity.

\section{Pathological criminal incapacity: A synopsis}

It is from the outset important to provide a brief prelude to the definition of the defence of pathological criminal incapacity as it currently operates within South African criminal law. Within the South African context the defence of pathological criminal incapacity is embodied and as such defined in Section 78(1) of the Criminal Procedure Act 51 of 1977 ("the Act"). ${ }^{16}$ Section 78(1) of the Act provides that an accused is not criminally responsible for an act of omission which constitutes an offence if at the time of the commission of the alleged offence the accused suffered from a mental illness or mental defect which rendered him or her incapable of appreciating the wrongfulness of his or her act; or of acting in accordance with an appreciation of the wrongfulness of his or her act. ${ }^{17}$ According to Snyman, the test for pathological criminal incapacity comprises of a pathological or biological leg which entails that the accused should have suffered from a mental illness or mental defect at the time of commission of the offence; and a psychological leg which entails that the accused should have, as a result of a mental illness or mental defect, lacked the capacity of appreciating the wrongfulness of the act or of acting in accordance with such appreciation. ${ }^{18}$ The test applied is accordingly

\footnotetext{
15 Dahl, P.R. Legal and Psychiatric concepts and the use of Psychiatric Evidence in Criminal Trials, California law review (1985) 411-442 at 411. See also Slovenko, R. Psychiatric Expert Testimony: Are the Criticisms Justified? (Part 1), Medicine and law (1991) 1-29.

16 Section 78(1) of the Act reads as follows:
}

"78 Mental illness or mental defect and criminal responsibility (1) A person who commits an act or makes an omission which constitutes an offence and who at the time of such commission or omission suffers from a mental illness or mental defect which makes him or her incapable-

(a) of appreciating the wrongfulness of his or her act or omission; or

(b) of acting in accordance with an appreciation of the wrongfulness of his or her act or omission, shall not be criminally responsible for such act or omission."

\footnotetext{
17 Snyman, C.R. Criminal law, 4 ed. LexisNexis (2008) 170; Burchell, J. and Milton, J. Principles of criminal law, 3 ed. Juta (2005) 373.

18 Snyman, C.R. supra note 17 at 172; Burchell, J. and Milton, J. supra note 17 at 377.
}

a so-called "mixed" test in that both the pathological as well as the psychological factors are taken into account in determining whether an accused lacked criminal capacity. ${ }^{19}$

The threshold requirement for the defence of pathological criminal incapacity is the existence of a mental illness or mental defect at the time of the commission of the act. The latter requirement is also referred to as the pathological leg of the test for criminal responsibility. The particular mental illness or mental defect must in addition render the accused incapable of appreciating the wrongfulness of his or her act, or acting in accordance with an appreciation of the wrongfulness of the act. ${ }^{20}$ The latter two defences apply in the alternative. Snyman as well as Burchell and Milton opine that "wrongfulness" for purposes of the appreciation of the wrongfulness of an act should denote either legal wrongfulness or moral wrongfulness. ${ }^{21}$

In respect of the defence of pathological criminal incapacity it is important to note that certain mental illnesses may not necessarily affect an accused's capacity to appreciate the wrongfulness of his or her action, but may nevertheless deprive the accused of the ability to control conduct or to act in accordance with the appreciation of wrongfulness. ${ }^{22}$

The test for pathological criminal incapacity or insanity does not define the terms "mental illness" or "mental defect" nor does it specify the particular mental disorders that constitute "mental illness" or "mental defect". What becomes evident is that the test only identifies the effects which should result from a particular "mental illness" or "mental defect". The pivotal role of the mental health professional in the definition and assessment of the mental illness becomes evident. A question which frequently arises is whether the definition of mental illness should be a medical or a legal prerogative. Slovenko pertinently encapsulates the dilemma as follows:

"During the past two centuries the courts have often said that the term "disease of the mind" or 'mental disease or defect' in the test of criminal responsibility is not a medical but a legal term. At the same time, however, since medical or psychiatric opinion is necessary to give meaning to the term, it becomes a fusion of legal and medical components. To be sure, no rule of law can be reliable when absolutely dependent on another discipline, but without input from other areas, the law would just be amid verbal agonizing."23

In respect of expert evidence by mental health professionals, a court is obliged in terms of Section 78(2) of the Act to refer an accused for observation if it is alleged at criminal proceedings that an accused is by reason of mental illness or mental defect not criminally responsible or if it appears to the court that an accused is for such a reason not criminally responsible. The matter is then enquired into and reported on in accordance with Section 79 of the Act which provides for the panel of experts who are required to conduct the assessment and comply with the procedural aspects associated therewith.

Within the realm of the defence of pathological criminal incapacity, a mental health expert requested to testify in support of such defence will inadvertently have to testify as to whether the accused at the time of the commission of the offence lacked either the capacity of appreciating the wrongfulness of the act, or of acting in accordance with such appreciation. As will be indicated below, the application of the ultimate issue rule could, however, more often than not place a barrier on the testimony by the mental health expert in terms of which the mental health expert is precluded from stating any conclusory opinions in respect of the mental state of the accused. In terms of the ultimate issue rule,

\footnotetext{
19 Ibid.

20 Snyman, C.R. supra note 17 at 172; Burchell, J. and Milton, J. supra note 17 at 377.

21 Snyman, C.R. supra note 3 at 173; Burchell, J. and Milton, J. supra note 3 at 380-381; Du Toit, E. et al. supra note 2 at 13-14.

22 Snyman, C.R. supra note 17 at 173; Burchell, J. and Milton, J. supra note 17 at 381.

23 Slovenko, R. The meaning of mental illness in criminal responsibility, The journal of legal medicine 1984:5:1-4.
} 
such prerogative remains a legal one and more specifically, rests with the fact finder. The question which inevitably arises is whether such barrier should be placed on the testimony and evidence of the mental health expert? Should the mental health expert not be allowed to present his or her evidence free from ultimate issue barriers? It is trite that it remains with the discretion of the fact finder which evidence to accept and which to reject.

\section{Relevance and the rules of expert evidence - Reflections from South Africa}

In order to comprehend the role of the mental health professional with reference to psychiatrists and psychologists within the paradigm of the defence of criminal incapacity, an understanding of the basic and foundational principles of expert evidence becomes essential. It has already been indicated above that expert evidence represents one of the exceptions to the general rule against opinion evidence. ${ }^{24}$ The opinion evidence of an expert will be deemed admissible if it is relevant in the sense that the expert by reason of specialised knowledge or skill is better qualified to draw an inference from the particular set of facts than the court itself. ${ }^{25}$

The evidence presented by mental health experts will be meaningless to the criminal justice system if it is not relevant to the issues before the court. ${ }^{26}$ Relevance in this sense can be deemed as one of the core requirements governing the admissibility of expert evidence within the criminal justice system. Relevance generally relates to the "probative potential of an item of information to support or negate the existence of a fact or consequence (factum probandum)." 27 Paizes and Zeffert state that relevancy essentially relates to a matter of common sense and reason. ${ }^{28}$

Section 210 of the Criminal Procedure Act reads as follows ${ }^{29}$ :

"No evidence as to any fact, matter or thing shall be admissible which is irrelevant or immaterial and which cannot conduce to prove or disprove any point or fact at issue in criminal proceedings."

Du Toit et al. similarly state that the relevance of an item of evidence entails its logical ability to show or indicate the material fact for which the evidence is adduced. ${ }^{30}$ Hiermstra notes that evidence which contributes to the proof or disproof of a fact in dispute is relevant and embraces evidence that directly proves matters in issue as well as those from which proof of a point in issue can be properly deduced and consequently all other evidence is irrelevant.

The principle of relevance will inadvertently play a pivotal role in respect of the admissibility of expert psychiatric or psychological evidence in support of the defence of criminal incapacity. Merely adducing such testimony will not necessarily suffice to comply with the requirement of relevance. An opinion of a mental health expert may thus be rendered inadmissible due to the irrelevance thereof. Conversely, such opinion may be admitted if found to satisfy the prerequisite of relevance.

It is trite that mental health professionals will, in cases where criminal incapacity is raised as a defence, be better qualified than the trier of fact to assess whether an accused in fact lacked criminal capacity at the time of the offence. The admissibility of expert evidence by mental health professionals will, however, be subject to the foundational principles governing expert evidence. There are generally four rules of

\footnotetext{
${ }^{24}$ Zeffert, D.T. and Paizes, A.P. supra note 2 at 310-312; Schwikkard, P.J. and Van der Merwe, S.E. supra note 2 at 87-88; Alan, A. in Tredoux et al. (eds) supra note 2 at 288; Du Toit, E. et al. supra note 2 at 24-17.

${ }^{25}$ Ibid. See also Ruto Flour Mills Ltd v Adelson (1) 1958 (4) SA 235 (T).

26 Zeffert, D.T. and Paizes, A.P. supra note 2 at 237-243.

27 Ibid.

28 Schwikkard, P.J. and Van der Merwe, S.E. supra note 2 at 45; Du Toit, E. et al. supra note 2 at $24-12$.

29 Criminal Procedure Act 51 of 1977.

30 Du Toit, E. et al. supra note 2 at 24-12.
}

expert evidence which regulate the reception and admissibility of opinion testimony by experts ${ }^{31}$ :

- The first rule relates to the so-called "expertise rule" or "specialist" rule. This rule requires assessment as to whether the witness possesses sufficient knowledge, skill or experience to render him or her an expert who can assist the trier of fact;

- The second rule is referred to as the "common knowledge rule" which entails an assessment as to whether the opinion sought from the witness relates to information beyond the ordinary or general knowledge of the court;

- The third rule is referred to as the "ultimate issue rule" in which case it has to be assessed as to whether the expert's opinion will be "usurping" the function of the court;

- The fourth rule relates to the so-called "basis rule". This rule requires an assessment as to whether the expert's opinion is founded on matters within the expert's own observation.

For purposes of this contribution, emphasis will be placed on the ultimate issue rule as this rule proves to be problematic in terms of the assessment and application of the defence of pathological criminal incapacity.

\section{The ultimate barrier: The ultimate issue rule}

Consider the following two opinions:

(i) "Mr Jones is insane."

As opposed to:

(ii) "Mr Jones suffered from paranoid schizophrenia that, in my opinion to a reasonable degree of medical certainty, impaired his ability to appreciate the wrongfulness of his act or to act in accordance with an appreciation of the wrongfulness of his act."

The two forms of opinion evidence which can be presented by mental health professionals as quoted above, encapsulates the salient features of the so-called "ultimate issue" rule in respect of expert evidence. In cases where mental health experts have to testify as to the mental state of the accused at the time of the commission of the offence, opinion (i) is regarded as an opinion on the "ultimate legal issue" which is regarded as an invasion of the legal arena and prohibited. Opinion (ii) is accordingly more preferable as the mental health expert refrains from expressing an opinion on the "ultimate issue" which is the lack or not of criminal capacity at the time of the offence which is regarded as a legal question and not a medical one. The viability of the ultimate issue doctrine is, however, questionable and presents several dilemmas in practice.

The ultimate issue rule generally provides that an expert witness may not be asked to provide opinion evidence concerning a matter which is regarded as an "ultimate issue" in a case. ${ }^{32}$ The ultimate issue rule is founded upon the fear that the function of the trier of fact may be "usurped" by the expert's exposition of expert evidence which deals with issues essential to the assessment of the case. ${ }^{33}$

Freckelton and Selby define "ultimate issue" $\mathrm{as}^{34}$ :

“... the central question which is the responsibility of the judge or jury to determine - an important issue of fact or law."

\footnotetext{
31 Freckelton, I. and Selby, H. Expert evidence in criminal law, Gaunt and Sons (2007) 2-3 Alan, A. and Meintjes-Van der Walt, L. in Kaliski (ed) supra note 2 at 343.

32 Freckelton, I. and Selby, H. supra note 31 at 277; Zeffert, D.T. and Paizes, A.P. supra note 2 at 313-319; Schwikkard, P.J. and Van der Merwe, S.E. supra note 2 at 87-88; Alan, A. and Meintjes-Van der Walt, L. in Kaliski (ed) supra note 2 at 345-346.

33 Ibid.

34 Freckelton, I. and Selby, H. supra note 31 at 277.
} 
Within the realm of the defence of criminal incapacity, the ultimate issue will inadvertently be whether the accused lacked criminal capacity at the time of the commission of the offence, or phrased differently, was "insane"; or whether the accused is incompetent to stand trial. The ultimate issue doctrine is problematic for mental health professionals requested to provide an opinion on the mental state of an accused as it is often difficult to express an opinion without addressing the ultimate issue itself. Melton et al. note that mental health professionals are often pressured to provide ultimate issue testimony. ${ }^{35}$ The numerous pressures on mental health professionals include the following ${ }^{36}$ :

(i) The presumption on the part of legal professionals that such expert testimony is an essential part of the mental health expert's presentation. In many instances the courts regard ultimate issue opinions as very important and often require conclusory testimony from the mental health professional;

(ii) Economic factors often play a role in respect of mental health professionals in private practice who may feel that their "market value" will lessen if they are too rigid in resisting providing opinions and conclusions easily obtainable elsewhere;

(iii) The structure and dynamics of the courtroom may also tempt the professional to address questions often beyond his or her expertise;

(iv) Mental health professionals are often prepared to provide ultimate issue testimony due to the fact that they believe that there is no ethical or legal prohibition against doing so.

Melton et al. encapsulate the clash between law and medicine in respect of the ultimate legal issue as follows ${ }^{37}$ :

"On the question of the ultimate legal issue, the relationship between the law and the mental health sciences invokes the analogy of a couple in psychotherapy who are locked in an overly dependent relationship. The legal system resists dealing with problems of its own by demanding that mental health professionals accept responsibility for them, conferring special status as an inducement. For their part, mental health professionals experience an increasing awareness of the unreasonable demands being made, but are unsure how to break the bond. Although both feel ambivalence, it is a relationship with old roots and considerable inertia."

In principle there are two approaches which could be followed in respect of the ultimate issue rule. On the one hand it could be argued that the ultimate issue rule serves the legitimate purpose of protecting the function of the trier of fact in prohibiting the mental health expert from expressing an opinion on the ultimate issue or as is often stated, "usurping" the function of the court. In this sense the mental health professional should refrain from expressing opinions on the ultimate issue and should stay within the boundaries of his or her field of expertise. On the other hand the question arises as to whether the ultimate issue rule serves any purpose. Melton et al. advocate in favour of an approach by which mental health professionals should "resist the ultimate issue question". ${ }^{38}$ In terms of this approach mental health professionals should refrain from presenting conclusory opinions which do not fall within their professional competence. ${ }^{39}$ Melton et al. state that although mental health professionals have a vast amount of expertise in their particular fields of specialisation, they do not have the necessary expertise to render ultimate legal judgments such as whether an accused person is incompetent or insane as these judgments are “...

\footnotetext{
35 Melton, G.B. et al. supra note 2 at 601.

36 Ibid.

37 Melton, G.B. et al. supra note 2 at 605.

38 Melton, G.B. et al. supra note 2 at 603-604

39 Ibid.
}

judgments that involve moral values and the weighing of competing social interests". ${ }^{40}$ Gutheil states that mental health experts should refrain from stating an opinion on the ultimate issue such as whether the accused is "insane" or not, but should rather present an opinion as to whether an accused with a reasonable degree of medical certainty, lacked capacity to appreciate the wrongfulness of his conduct, or, in line with the capacity test in South Africa, lacked the capacity to act in accordance with such appreciation. ${ }^{41}$ Expert evidence in the latter fashion will consequently avoid the so-called "battle of the experts" whilst enhancing the trier of fact's understanding of the clinical data. ${ }^{42}$ It is, however, often difficult for mental health professionals not to answer the ultimate issue when presenting their opinion. The question which falls to be assessed is whether there is a need for the perpetuation of the ultimate issue rule. Should the opinion of a mental health professional not rather be judged according to its relevance? A decision which is of relevance in this regard is Holtzhauzen v Roodt. ${ }^{43}$ It is to be noted that although this decision did not pertinently deal with the defence of pathological criminal incapacity, it nevertheless becomes relevant for purposes of the application of the ultimate issue rule. The salient facts of this decision were briefly as follows.

The plaintiff sued the defendant for defamation arising from reports she made to her mother and allegedly her close friend and sisters consisting of a statement that she had been raped by the plaintiff. The defendant consequently gave notice in terms of Rule 39(9) of the Uniform Rules of Court of his intention to call two expert witnesses, Mr Wilkinson and Ms Breslin. Mr Wilkinson was a qualified clinical psychologist and a member of the South African Society of Clinical Hypnosis; and Ms Breslin had a master's degree in social work and was the clinical supervisor of "People Opposing Woman Abuse" which dealt with the counselling of women who had been raped or who were in abusive relationships. Mr Wilkinson's testimony was to the effect that the defendant had consulted him on a number of occasions and had told him that she had been raped by the plaintiff and, furthermore, that she had also done so twice whilst under hypnosis during hypnotherapy sessions. Mr Wilkinson's opinion further stated that the defendant was telling the truth about the relevant incident. Ms Breslin's testimony stated that women who had been raped would not often reveal the incident to third parties immediately after it had occurred and that it was common for such victims to exhibit radical changes in behaviour. The plaintiff opposed the admission of the evidence of Mr Wilkinson and Ms Breslin on the basis that Mr Wilkinson's evidence usurped the function of the court and amounted to evidence of the content of a previous consistent statement; and further that Ms Breslin's evidence was of a general nature as she had had no consultation or discussion with the defendant and accordingly that the evidence was irrelevant. Before dealing with the remarks made by Satchwell $\mathrm{J}$ as to the relevance of each of the experts' opinions, it is necessary to look at the findings rendered in respect of expert evidence and the admissibility thereof. Satchwell $\mathrm{J}$ held the following in respect of expert evidence ${ }^{44}$ :

(i) The expert witness must be called to give evidence on matters calling for specialised skill or knowledge. The court will have to determine whether the subject of enquiry involves issues calling for specialised skill or knowledge. Evidence of opinion on matters which do not call for expertise is excluded as it does not help the

41 Simon, R.I. and Shuman, D.W. (eds) Retrospective Assessment of Mental States in Litigation: Predicting the Past in T.G. Gutheil, Mastering forensic psychiatric practice: Advanced strategies for the expert witness, American Psychiatric Pub. (2002) 94; Melton, G.B. et al. supra note 2 at 604 .

42 Ibid.

${ }^{43}$ Holtzhauzen $v$ Roodt 1997 (4) SA 766 (WLD). See also Du Toit, E. et al. supra note 2 at 24-16B; Schwikkard, P.J. and Van der Merwe, S.E. supra note 2 at 94-96. It is notable that there are currently no decisions where the defence of pathological criminal incapacity was raised as defence where the ultimate issue rule was pertinently addressed.

44 At 772 B-773 C.
} 
court. At best, it is superfluous and, at worst, it could be a cause of confusion. ${ }^{45}$

(ii) The courts are accustomed to receiving the evidence of psychologists and psychiatrist, particularly in criminal courts. However, the expertise of the witness should not be elevated to such heights that sight is lost of the court's own capabilities and responsibilities in drawing inferences from the evidence. ${ }^{46}$

(iii) The witness must be a qualified expert. It is for the judge to determine whether the witness has undergone a course of special study or has experience or skill as will render him or her an expert in a particular field. It is not essential for the expertise to have been acquired professionally. ${ }^{47}$

(iv) The facts upon which the expert opinion is based must be proved by admissible evidence. Such facts either fall within the personal knowledge of the expert or form the basis of facts proved by others. If the particular expert has observed them, then the expert must testify as to their existence. The expert must further provide criteria for testing the accuracy as well as the objectivity of his or her conclusion and the court must be informed of the basis upon which the opinion is based. Due to the fact that the testimony of an expert will carry more weight, higher standards of accuracy and objectivity should be required. ${ }^{48}$

(v) The guidance offered by the expert must be sufficiently relevant to the matter in issue which is to be determined by the court. ${ }^{49}$

(vi) Opinion evidence must not usurp the function of the court. The witness is not permitted to give an opinion on the legal or general merits of the case. The evidence of the opinion of the expert witness should not be presented on the ultimate issue. The expert should not be required to answer questions which the court has to decide. ${ }^{50}$

The main issue in this case related to the relevance and admissibility of the expert opinions of Mr Wilkinson and Ms Breslin. With regard to Mr Wilkinson's testimony, Satchwell J held that it was not relevant for a number of reasons, of which the most important are the following:

(i) The greatest part of the evidence of Mr Wilkinson was to refer the court to consultations which he had with the defendant during which she made particular statements to him. The only reason for the advancement of these statements was to indicate consistency in the statements made by the defendant prior to her giving evidence in court. Satchwell J held that these statements were superfluous. ${ }^{51}$

(ii) The conclusion expressed by Mr Wilkinson displaced the value judgement of the court. Satchwell J in addition held: ${ }^{52}$

"It is required of this court to make certain determinations on its own on an assessment and on an evaluation of all the evidence that has been placed before the court and not just on the version as presented by the defendant." 53

(iii) It is an established principle that litigants should have their disputes resolved by judges and not by witnesses. ${ }^{54}$ Satchwell J further held ${ }^{55}$ :

\footnotetext{
45 At 772 C-D.

46 At 772 E-G. See also S v Kalogoropoulos 1993 (1) SACR 12 (A) at 22 D-E.

47 At $772 \mathrm{H}$.

48 At 772 I-773 B.

49 At 773 B.

50 At 773 C.

51 At 774 C-D.

52 At 774 F.

53 At $774 \mathrm{G}-\mathrm{H}$.

54 At $774 \mathrm{H}-\mathrm{I}$.

55 At 774 I-J.
}

"If the Wilkinson's of the world are too readily allowed to give their opinions on the subject-matter of litigation, then this would lead to the balancing of opinion as between witnesses. This would tend to shift responsibility from the Bench to the witness-box."

(iv) The evidence to be presented by Mr Wilkinson regarding the hypnosis and the conditions under which the statements were made by the defendant usurped the judgement of the court. ${ }^{56}$

In respect of Ms Breslin's evidence Satchwell J held that the guiding criteria in the assessment of relevance in respect of Ms Breslin's evidence were whether it was "helpful" and "of assistance to the court". ${ }^{57}$ It was further held that the test with regard to the admissibility of expert evidence was whether a court, by reason of its lack of special knowledge and skill, was not sufficiently informed to enable it to venture the task of drawing properly reasoned inferences from the facts established by the evidence and consequently expert opinion will be admitted if such expert is by reason of special knowledge or skill better equipped than the court to advance, reject and comment on certain inferences in order to assist the court. ${ }^{58}$ Satchwell $\mathrm{J}$ held that the rape of a woman is an experience of utmost intimacy and that the ability of a judicial officer to fully comprehend the "kaleidoscope of emotion and experience of both rapist and rape survivor is extremely limited". 59 Satchwell $\mathrm{J}$ in addition held that it would be unwise for a judicial officer lacking special knowledge and skill to draw inferences from facts which have been proved by evidence in the absence of granting an expert in the field the opportunity to provide guidance on the specific aspect. ${ }^{60}$ Expert evidence could provide guidance as to why the rape victim failed to immediately (or at the first possible opportunity) report the rape. ${ }^{61}$ Satchwell J accordingly held that the evidence of Ms Breslin was admissible but stated the following ${ }^{62}$ :

"At the end of the day, however, I must stress that the value which I will attach to such evidence will fall to be assessed in the light of all the evidence before the court; that is the evidence of the defendant, of the plaintiff and his wife, of their son and nephew, of the defendant's mother and her sisters. The guidance and opinion of Ms Breslin will merely be one pointer of assistance. It remains for the court to determine the probative value of Breslin's evidence and in what manner and to what extent it is of use in understanding the facts before the court."

If one were to reflect on the Holtzhauzen decision it becomes clear that the evidence of the experts was assessed as to its admissibility on the backdrop of the basic tenet in the law of evidence - its relevance and helpfulness. It is unfortunate that the ultimate issue rule was once again reaffirmed. It is clear that the evidence of Mr Wilkinson was irrelevant. His evidence failed the threshold test of relevance and on that basis it was held inadmissible. It could thus be argued that the argument of Mr Wilkinson "usurping" the function of the court was unnecessary and superfluous which results in questions arising as to the viability of this rule. Despite the fact that the Holtzhauzen decision was a civil hearing, the principles enunciated therein can also be applicable to the presentation of expert evidence in cases where criminal incapacity is raised as a defence.

Zeffert and Paizes correctly state that the Holtzhauzen decision provides a good example of when the opinion of an expert witness is

\footnotetext{
56 At 775 A.

57 At $776 \mathrm{G}-\mathrm{H}$

58 At 777 H-J.

59 At $778 \mathrm{~F}-\mathrm{H}$

60 At 778 I-J.

61 At 778 I-779 C

62 At 779 C-E.
} 
provided on the issue which the court ultimately has to assess. ${ }^{63}$ Zeffert and Paizes ${ }^{64}$ correctly note that it is unfortunate that the court, whilst, rightly basing its assessment on considerations of relevancy and achieving the correct result, resorted to the meaningless expression of "usurping the function of the court" which, as has been submitted, may obfuscate the fact that the court in assessing whether to accept expert opinion on an ultimate issue, is concerned with a flexible and practical concept that expresses "the need for relevance". ${ }^{65}$

The ultimate issue rule and consequently the rule that an expert witness should not usurp the function of the court have been described by Wigmore as a "mere bit of empty rhetoric". ${ }^{66}$ Wigmore correctly notes that there is no reason for such rule as the witness is not attempting to "usurp" the function of the tribunal of fact as he or she is merely offering a portion of testimony which could still be rejected in favour of an alternative view. ${ }^{67}$ Within the South African legal system where there is no jury system anymore, it is submitted that the ultimate issue rule is redundant and superfluous. Expert evidence from psychiatrists and psychologists should be received or rejected on the basis of its relevance and helpfulness.

Meintjes-Van der Walt correctly states that even where expert evidence is allowed on the ultimate issue, it remains evidence to be weighed by the trier of fact and accordingly the admission of such evidence does not imply reliance on such evidence. ${ }^{68}$ Expert opinion evidence should be judged on the basis of its relevance to the issues before the court and whether it can adequately assist the trier of fact in the assessment of the relevant issues. It could further be argued that mental health professionals, taking into consideration the boundaries of their own professional expertise, should be allowed to express their opinions liberally with regard to the findings as to the mental state of an accused person. At the end of the day it remains within judicial discretion to determine the appropriate weight to be accorded to such evidence. In Ruto Flour Mills Ltd v Adelson (1), ${ }^{69}$ Boshoff J held the following ${ }^{70}$ :

"An expert's opinion is received because and whenever his skill is greater than the court's ... The fact that an expert expresses an opinion on a matter which the court has to decide does not, in itself, make the evidence inadmissible ... where the issue involves other elements besides purely scientific, the expert must confine himself to the latter and must not give his opinion upon the legal or general merits of the case. Where, however, the issue is substantially one of science or skill merely, the expert may, if he has himself observed the facts, be asked the very question which the jury have to decide."

This quotation could also be applied to the sciences of psychiatry and psychology. From a psychiatric perspective, Halleck notes that psychiatric testimony is generally required for purposes of providing facts of an accused's mental illness; to provide opinions relating to the nature of that illness; and to provide opinions as to whether the individual's illness was of such a nature to render him or her legally insane. ${ }^{71}$ Halleck suggests that it is the third task which is more often than not, problematic as the process of converting clinical data into opinions as to how mental illness renders an individual legally insane and negating criminal responsibility, is a task for which a psychiatrist has "no training, no science, and no theories to guide him". ${ }^{72}$ The cornerstone for the

\footnotetext{
63 Zeffert, D.T. and Paizes, A.P. supra note 2 at 318; Schwikkard, P.J. and Van der Merwe, S.E. supra note 2 at $88-89$.

64 Ibid.

65 Emphasis added.

66 Wigmore, J.H. Evidence in trials at common law, Little, Brown (1978) 18-19.

67 Ibid.

68 Meintjes-Van der Walt, L. supra note 2 at 166.

${ }^{69}$ Ruto Flour Mills Ltd $v$ Adelson 1958 (4) SA 235 (TPD).

70 At 237 A-F.

71 Halleck, S.L. Law in the practise of psychiatry - A handbook for clinicians, Plenum Medical Book Co. (1980) 213.

72 Ibid.
}

admission of such testimony should be relevance and helpfulness and not whether the witness addresses the ultimate issue. Slovenko correctly states that, similar to other forms of evidence, the trier of fact retains a discretion to exclude expert evidence if it is established that its probative value is substantially outweighed by its prejudicial effect or if its admission would confuse the issues, result in a delay of the proceedings or waste of judicial resources. ${ }^{73}$ Slovenko in addition states ${ }^{74}$ :

"Ultimately, the rule simply ignores the principle that the touchstone in the law of expert evidence is helpfulness."

Gilmer, Louw and Verschoor submit that there are principally two motivations why mental health experts should refrain from providing opinions on ultimate legal issues - the first reason relates to the ethical dilemma of purporting to be scientific where there are no bases for such pretension. The second reason relates to instances where the expert by doing so "usurps" the function of the court. ${ }^{75}$ Gilmer, Louw and Verschoor note that a court may admit whatever evidence it deems fit in a specific case, weigh the probative value thereof and assume responsibility for the result which follows. ${ }^{76}$ Where an expert, however, seeks to express an opinion beyond that arising from knowledge, training and expertise, the expert will cease in providing an expert opinion and venture into providing "an illegitimate opinion as a person who happens to be an expert in a non-relevant field". ${ }^{77}$ According to Gilmer, Louw and Verschoor the question as to whether a witness is "usurping" the function of the court, is in principle the court's concern and they state the following ${ }^{78}$ :

"The expert's concern is to remain within the generally accepted terrain of that discipline and to follow the court's direction as to the questions the court desires be answered."

Mental health professionals should be permitted to testify as to their clinical findings in respect of an accused. Whether the opinion testimony is couched in terminology of a conclusory nature should be of less concern and should yield to the greater need for assessing the mental state of the accused at the time of the offence as comprehensively and thoroughly as possible.

\section{Federal Rule 704 - Instrument of help or doom?}

It was during summer in 1976 when a young John Hinckley, Jr, watched Travis Bickle plot to assassinate a presidential candidate in the film 'Taxi Driver'. Hinckley instantaneously fell in love with actress Jodie Foster who played the role of a 12-year old prostitute in the film. Hinckley developed an obsession with Jodie Foster and the President. This obsession culminated in Hinckley shooting and wounding President Ronald Reagan on 30 March 1981 in an attempt to impress Jodie Foster. $^{79}$

Various psychiatrists testified for the defence and due to the fact that Hinckley suffered from "process Schizophrenia" they unanimously concluded by stating that he was insane when he shot the president. Despite contradictory expert evidence by prosecution psychiatrists, the

\footnotetext{
73 Slovenko, R. Commentary: Deceptions to the Rule on Ultimate Issue Testimony, Journal of American academy of psychiatry and the law (2006) 25.

74 Ibid.

75 Gillmer, B.T., Louw, D.A. and Verschoor, T. Forensic Expertise: the Psychological Perspective, Psychological medicine (1984) 291.

76 Ibid.

77 Ibid.

78 Ibid.

79 Rogers, R. and Ewing, C.D. Ultimate Opinion Proscriptions: A Cosmetic Fix and a Plea for Empiricism, Law and human behavior (1980) 357-358. See also "The Hinkckley Trial: Hinckley's Communications with Jodie Foster" at http://www.law.umke.edu/faculty/ projects/ftrials/hinckley/jfostercommun.HTM [accessed on 2010/03/09].
} 
jury nevertheless found Hinckley not guilty by reason of insanity. ${ }^{80}$ These facts are used to set the stage for the proper comprehension as to how it came about that Federal Rule 704 was eventually amended to make provision for Federal Rule 704(a) and (b) of the Federal Rules of Evidence which deals with opinion evidence pertaining to ultimate issues.

The semantics and characteristics of the ultimate issue rule have already extensively been assessed above. It was indicated that the author supports the abdication of the ultimate issue rule in support of a more liberal approach towards the admission of expert evidence. It was in addition noted that relevance should be the determining factor in respect of the admissibility of expert evidence and not necessarily whether the expert opinion embraces an ultimate issue.

In this section it is necessary to reflect on the ultimate issue doctrine as espoused in the Federal Rules of Evidence.

Federal Rule 704 states the following pertaining to opinion evidence on ultimate issues ${ }^{81}$ :

“(a) Except as provided in subdivision (b), testimony in the form of an opinion or inference otherwise admissible is not objectionable, because it embraces an ultimate issue to be decided by the trier of fact.

(b) No expert witness testifying with respect to the mental state or condition of a defendant in a criminal case may state an opinion or inference as to whether the defendant did or did not have the mental state or condition constituting an element of the crime charged or of a defence thereto. Such ultimate issues are matters for the trier of fact alone."

When the Federal Rules of Evidence were introduced in 1975, it originally only more or less provided for part (a) as quoted above and accordingly expressly permitted expert opinions to embrace an ultimate issue provided it was helpful in assisting the trier of fact. ${ }^{82}$ The common law ultimate issue rule was thus abolished as a result of Federal Rule $704 .{ }^{83}$ In 1985 , in the aftermath of the Hinckley verdict, Federal Rule 704 was amended and the ultimate issue rule was reinstated in cases where the mental state of a person had to be determined. ${ }^{84}$ The former Federal Rule 704 merely provided that:

"Testimony in the form of an opinion or inference otherwise admissible is not objectionable because it embraces an ultimate issue to be decided by the trier of fact." 85

The amendment of Federal Rule 704 was specifically aimed at curbing expert testimony in cases of insanity. ${ }^{86}$ Rogers and Ewing explain that the amended rule does not completely prohibit expert evidence in insanity trials, but that such opinions may not include statements of opinion concerning so-called ultimate issue opinions. ${ }^{87}$

The Hinckley trial took place before the enactment of Federal Rule 704(b). It is interesting to note that the experts called by the defence unanimously held that Hinckley was psychotic when he shot the president, whilst all of the experts called for the prosecution tendered

81 Federal Rule 704. See also Melton, G.B. et al. supra note 2 at 16; Freckelton, I. and Selby, H. supra note 31 at 293-294.

82 Slovenko, R. supra note 73 at 22; Buchanan, A. Psychiatric Evidence on the Ultimate Issue, The journal of the American academy of psychiatry and the law (2006) 14.

83 Ibid.

84 This amendment was enacted by means of the Insanity Defence Reform Act of 1984,

Title IV, Pub. L. No. 98-473, 98 Stat. 2067 (1984). See Buchanan, A. supra note 82 at 14; Slovenko, R. supra note 73 at 22.

85 Rogers, R. and Ewing, C.P. Ultimate Opinion Proscriptions: A Cosmetic Fix and a Plea for Empiricism Law and human behavior (1989) 357-359; Slovenko, R. supra note 73 at 22-23.

86 Ibid.

${ }^{87}$ Rogers, R. and Ewing, C.P. supra note 85 at 360.
}

evidence that Hinckley was not psychotic at the time of the act. ${ }^{88}$ Defence experts contended that the shooting was the sole consequence of Hinckley's delusional thoughts that shooting the president would win him the love of much-adored film star Jodie Foster. Prosecution experts, on the other hand, argued that Hinckley shot the president as a result of a narcissistic desire to become famous. ${ }^{89}$ Rogers and Ewing interestingly note that in the event of Hinckley having been tried after Rule 704 was amended the experts would not have been permitted to express a direct conclusion as to whether Hinckley had the capacity to appreciate the wrongfulness of his conduct or the ability to conform his conduct with the requirements of the law. However, the bulk of the remaining part of their testimony which typically falls within the zone of the "battle of the experts" would still have been admissible. ${ }^{90}$

In order to assess the viability of the ultimate issue doctrine, now within the American context, it is necessary to reflect on both sides of the coin to this rule and thus the reasons in support of the reinstatement of the rule as opposed to the arguments against the rule.

Rogers and Ewing state that the submissions in favour of the proscription on ultimate opinions pertaining to the mental status of individuals are the following ${ }^{91}$ :

(i) Professional taint

This argument seeks to curb the role of mental health professionals in insanity trials in an attempt to avoid public and collegial disapproval as well as the so-called "appalling circus atmosphere" which follows when mental health professionals present conflicting opinions pertaining to ultimate issues.

(ii) Insufficient clinical data

This argument is premised upon the untested assumption that mental health professionals render such opinions in the absence of adequate clinical observations, test results or explicit databased opinions and decision-making.

(iii) Undue influence

This argument is founded on the assumption that ultimate issue testimony will unduly influence the trier of fact or usurp the function of the jury.

(iv) Lack of legal and moral expertise

This argument is also often referred to as definitional exclusion. Legal professionals as well as some mental health professionals often contend that ultimate opinions are moral and not psychological in origin. The latter comment was espoused by the House Committee Report in 1984, which supported the 1984 Amendment, where it was stated ${ }^{92}$ :

"While medical and psychological knowledge of expert witnesses may well provide data that will assist the jury in determining the existence of the (insanity) defense, no person can be said to have expertise regarding the legal and moral decision involved. Thus with regard to the ultimate issue, the psychiatrist, psychologist or other similar expert is no more qualified than a lay person."

Cohen in addition notes that the rationale behind the enactment of Federal Rule 704(b) was further that mental health experts often express impermissible legal conclusions despite their lack of legal expertise. ${ }^{93}$ The latter occurs when an expert incorrectly testifies that an individual was sane or insane as a result of the reliance placed on

\footnotetext{
88 Ibid.

89 Ibid.

90 Ibid.

91 Rogers, R. and Ewing, C.P. (1989) supra note 85 at 361-364; Buchanan, A. supra note

82 at 16-17; Slovenko, R. supra note 73 at 23-25.

92 Rogers, R. and Ewing, C.P. supra note 85 at 30; Buchanan, A. supra note 82 at 16.

93 Ibid.
} 
an incorrect standard when rendering an opinion. ${ }^{94}$ The objection most frequently raised in support of the proscription on ultimate issue testimony relates to the fact that expert testimony pertaining to the issue of an individual's mental condition invades the province of the trier of fact or, within the American context, the jury. ${ }^{95}$

Despite the statutory basis of the ultimate issue proscription and accordingly the prohibition on ultimate opinions in respect of the mental state or condition of an individual in a criminal case, it becomes clear that there is a strong opposition to this rule as will be addressed below.

The ultimate issue rule contained in Federal Rule 704(b) may on face value seem quite attractive especially to those sceptical of the abilities of mental health experts. Research, however, indicates that this rule is unsatisfactory in practice. The various arguments against this rule will be summarised below.

- Clinical judgments and clinical observations are inseparable - forensic assessments and insanity evaluations are both structured and determined to a large extent by the examiner's initial judgements pertaining to the individual's history and presentation..$^{96}$ Such judgement not only sets the parameters of the evaluation, but also dictates the expert's interpretation of the clinical observations. These observations ${ }^{97}$ are also structured in accordance with the expert's evolving clinical assessments. Denying the expert the opportunity to present these judgments does not alter but conceals their value and impact. $^{98}$

Accordingly, triers of fact will have no way of evaluating the assumptions that eventually resulted in the interpretation of the expert's assessments and there will be no way by which to assess the weight and probative value to be accorded to the expert's observations. ${ }^{99}$

- Even in the event of fact finders or juries being inclined to blindly adopt and accept psychiatric testimony, Rule 704(b) would not remedy the problem. ${ }^{100}$ The mental health expert would generally be permitted to state a diagnosis and explain the phenomena of the disease even though the presence of the disease is also an ultimate issue for the trier of fact or jury. ${ }^{101}$ Cohen ${ }^{102}$ explains that, if courts allow opinion testimony that logically requires the jury to reach a certain conclusion and then refuse to allow the expert to state the conclusion, the jury might erroneously assume that it arrived at the conclusion itself and as such jurors are likely to be more overawed by their own conclusions of even the most impressive witness.

- Federal Rule 704(b) negatively impacts on an accused's (defendant's) right to introduce expert testimony.

- Ultimate opinions are an inevitable and inescapable result of the forensic assessment process. ${ }^{103}$ The main goal of any insanity assessment is to reach an informed conclusion as to a defendant's criminal responsibility. The ultimate opinion rule poses an impossible situation in terms of which the mental health expert is expected to strive towards a highly specific goal, but also to abandon that goal in the final stage. ${ }^{104}$ The evidence of such a mental health expert will inadvertently appear contrived and leave the trier of fact with the prospect to "read between the lines" and to assess precisely what the expert knew but failed to disclose. ${ }^{105}$

\footnotetext{
94 Ibid.

95 Ibid.

96 Rogers, R. and Ewing, C.P. supra note 85 at 364-365.

97 Ibid.

98 Ibid.

99 Ibid.

100 Cohen, D. Punishing the Insane, University of Florida law review (1988) 577.

101 Ibid.

102 Ibid.

103 Rogers, R. and Ewing, C.P. supra note 85 at 365.

104 Ibid.

105 Ibid.
}

- It is impossible to meaningfully distinguish between ultimate opinions and ordinary expert opinions. ${ }^{106}$ During the course of insanity assessments, mental health experts often render scores of judgments pertaining to a defendant's condition and the relevance of that particular condition to the alleged criminal conduct. ${ }^{107}$ The ultimate opinion rule strives to single out particular judgments and to restrain experts from making or at the very least, reporting them to the triers of fact. ${ }^{108}$

- Prohibitions on ultimate opinions may paradoxically expand the scope of expert testimony by mental health professionals within the insanity context. ${ }^{109}$

- Prohibitions on ultimate opinions may result in mental health experts exercising less care in their assessments of criminal responsibility. ${ }^{110}$

- Federal Rule 704(b) admits the most confusing expert testimony, the mental health expert's diagnosis, whilst excluding the least confusing testimony, the expert's opinion as to the mental state or sanity of the defendant. $^{111}$

It is clear that there is much controversy surrounding Federal Rule 704(b). Although penultimately framed in statutory form, this rule is unworkable and problematic as it leads to unnecessary complications in the application of the insanity defence. In order to adequately adduce and challenge evidence, it is pivotal that such evidence be tendered as comprehensively and informatively as possible. Federal Rule 704(b) unnecessarily restricts the presentation of expert evidence in insanity trials. It is clear that the addition to Federal Rule 704 has not produced success. Cohen correctly asserts that Rule 704(b) mandates the exclusion of relevant and probative evidence in the fear that it may be too persuasive and exclusion as such is prejudicial to the criminal justice system. $^{112}$

Federal Rule 704(a) can be welcomed also in comparison with South Africa where no such rule is codified. Federal Rule 704(b) is, however, an unnecessary amendment to the rules of evidence and as such superfluous. Slovenko submits that Federal Rule 704(b) renders expert witnesses less useful to triers of fact as it enhances indirect and incomplete testimony. ${ }^{113}$ Rogers and Ewing correctly propose the elimination of the terminology "ultimate opinion" due to the fact that when opinions are at issue, the "ultimate is, by definition, unattainable". ${ }^{114}$ Rogers and Ewing encapsulate the latter by stating ${ }^{115}$ :

"The expert's opinion is not even penultimate, for it is the judge who instructs the jury as to how to weigh the evidence and reach its "ultimate" judgment. At best, the mental health expert renders what might be called an antepenultimate opinion."

It is submitted that a rule similar to Federal Rule 704(a) is a welcoming response to the traditional ultimate issue rule and a similar rule could be usefully applied within the South African context. Federal Rule 704(b) unnecessarily restricts the presentation of expert evidence in insanity trials.

It is submitted that mental health experts should be afforded the opportunity to adequately testify as to their clinical findings as well as their opinions pertaining to their findings. Anything less will be a failure of the ultimate pursuit for truth and justice whenever the defence of pathological criminal incapacity falls to be assessed.

\footnotetext{
${ }^{106}$ Rogers, R. and Ewing, C.P. supra note 85 at 365-367.

107 Ibid.

108 Ibid.

109 Ibid.

110 Ibid.

111 Cohen, D. supra note 100 at 559; Buchanan, A. supra note 82 at 17

112 Cohen, D. supra note 100 at 561.

113 Slovenko, R. supra note 73 at 25.

114 Rogers, R. and Ewing, C.P. supra note 85 at 373.

115 Ibid.
} 